\title{
An Economic Study on Income and Expenditure Activities on Nochikuppam Slum Areas, Chennai City
}

\author{
M. ARULMURUGAN \\ Ph.D research Scholar, \\ Department of Economics, Thiru.Vi.Ka Govt.Arts College, Thiruvarur \\ Affiliated to Bharathidasan University Tiruchirappalli, Tamil Nadu, India. \\ Dr. V. Thandapani \\ Assistant Professor and Head, \\ D.G. Government Arts College, Mayiladuthurai, Tamilnadu.
}

\begin{abstract}
The dimension of the slums is presumed as something that is deteriorating urban areas that is densely populated and contains dilapidated housing, often in multiple occupations, poverty, social disadvantage and other forms of physical and social deprivation. Urbanization is a global phenomenon experienced by economically advanced as well as developing countries. Rapid urbanization due to "pull factor" or the employment opportunity created in the city and "push factor" due to the lack of the same in rural areas and including environmental degradation, has attracted immigrants not only from the rural Tamil Nadu but also from other parts of the country. Growth of industrialization around the Chennai city, famine situation in the rural area, inadequate rain in the rural area, castism, rapidly and vast building construction activity in and around the city and information technology parks, has given surety for skilled, unskilled, semi-skilled jobs which are available to the deserving people. Most of the immigrated families who could not afford formal housing satisfy their need for housing by occupying available vacant land illegally and solving their housing problem and contribute to the creation of slums. In this study mainly aims to the income and expenditure activities of the Nochikuppam slum areas in Chennai city.
\end{abstract}

Keywords: Slums, urban slums, slum poverty, Urbanization and slum. 


\section{Prelude}

The urban local bodies are self-governing agencies, their functions are essential inputs in the lives of the citizens. Although the functions of the urban local bodies are categorized under the obligatory and discretionary functions, the local bodies are finding it difficult to extend the obligatory functions due to limited resources and absence of technical skills. The local body can justify its role only with the successful delivery of the listed obligatory and discretionary functions. In view of the complex problems faced by the local bodies, they should deal with the situation by delivering new functions both in magnitude and direction. These new functions include guiding the citizens in building their houses, strengthening the public health services, providing environmental inputs and extending social welfare and recreational facilities. The urban local bodies should be strengthened in view of the growing responsibilities. The state governments should guide them to overcome the difficulties encountered in the delivery of the listed functions.

Today, urban local bodies are deemed as an asset distribution centers, every citizen is demanding the services without realizing their individual roles. 'We' feeling among the urban citizen has to be developed. Unless each citizen realize his role the tasks of the municipality cannot be easily realized. Moreover, role of the urban local bodies should not confined to provision of civic amenities. Provision of civic amenities is not an end to the problem; it should become means to extend local welfare. It can be achieved only with the committed political will and honest executives.

Slums are cancerous for urban life and no effort should be spared to eradicate them. No doubt, they are manifestation of socio-economic conditions prevailing in the country but if no heed is paid to contain them, urban life will become not only miserable but unbearable. A serious policy of urban development, based on sound principles of town planning and efficient administration, committed to the service of the humanity with vast financial resources and authority can only successfully combat the problems of slums.

They are a bye-product of urbanization and industrialization. Slum-dwellers are the real architect of urban facilities but their own life is endangered with poor facilities made available to them. Because of the laxity on the part of the municipal government, these slums sprang up and later on become difficult to control.

"Slum" is defined as that area where the buildings are in any respect unfit for human habitation; or by reason of dilapidation, overcrowding, faculty arrangement of buildings, streets, lack of ventilation, light or sanitation facilities or combination of these factors, are detrimental to safety, health or morals (Slums Improvement and Clearance Act, 1956). Approximately, $68.8 \%$ of the country's slums population was concentrated in the 300 class I cities and less than $1 / 3^{\text {rd }}$ of this population resides in the remaining 3300 urban centers. 


\section{Statement of the problem}

The idea of slum is very lucid. The dimension of the slums is presumed as something that is deteriorating urban areas that is densely populated and contains dilapidated housing, often in multiple occupations, poverty, social disadvantage and other forms of physical and social deprivation. Urbanization is a global phenomenon experienced by economically advanced as well as developing countries. The increasing movement of people from villages to towns and cities continue to scale up, as countries place emphasis on industrial development. In general, cities and towns provide large economics o f agglomerations and provide a variety of choices in terms of economic opportunities and urban life styles for the people. Rapid urban development has brought in its wake an alarming inevitable and persistent growth o f slums where living environment is pathetic. In India there is an acute problem o f slums not only in big cities but also in medium and small towns. As an observation, most of the Indian small towns are much congested and unhygienic although their effect on an individual is mitigated by the openness of the environment. For a planned healthy growth of a small town it is essential to check the problem of slums at their primary stage. The study o f dynamics of slum formation is not limited with the information of the physical aspects, but to understand the process through the experience of the dwellers and using the same for evaluation. Such is the magnitude of the shelter problem in a mad world o f profit hunt, urbanizing chaotically. 2 The slum became part of the urban complex created by industrial revolution. As Lewis Mumford puts it, the factory, the railway road and the slum existed together. There are various characteristic features of a slum like inadequate housing, lack o f basic amenities, overcrowding, unhygienic surrounding etc, however it is a community in process and a way o f living. Moreover it is a subsystem in a large urban system which is characteristic by attributes. The increasing numbers of people who have taken up residence in cities and the large scale urbanization that has gained momentum due to the multifunctional character of the city has created serious problem in respect of urban facilities especially housing. This type of flow is bound to create slums in the long run, irrespective of the fact, whether it is an industrial city or not. Assam being the gateway to North-East India has attracted a lot of people and therefore we tend to find slum formation in many over crowed areas where basic amenities like water, drainage etc. are lacking. Therefore, it is time that one makes a serious attempt to study the problems and how it could be mitigated. In the last three decades the population of Chennai city has grown from 8.56 lakhs to over 30 lakhs i.e. around 62 percent growth. Rapid urbanization due to "pull factor" or the employment opportunity created in the city and "push factor" due to the lack of the same in rural areas and including environmental degradation, has attracted immigrants not only from the rural Tamil Nadu but also from other parts of the country. Growth of industrialization around the Chennai city, famine situation in the rural area, inadequate rain in the rural area, castism, rapidly and vast building construction activity in and around the city and information technology parks, has given surety for skilled, unskilled, semi-skilled jobs which are available to the deserving people. Most of the immigrated families who could not afford formal housing satisfy their need for housing by occupying available vacant land illegally and solving their housing problem and contribute to the creation of slums. In this study mainly aims to the income and expenditure activities of the Nochikuppam slum areas in 
Chennai city and also it assumed that there is a significant relationship between the income and expenditure of the sample respondents. In this study mainly based on primary data with the help of schedule and also take 58 samples from 5369 samples.

Monthly income wise expenditure details

\begin{tabular}{|l|c|c|c|c|c|}
\hline $\begin{array}{l}\text { Monthly } \\
\text { expenditure }\end{array}$ & $\begin{array}{c}\text { Below Rs } \\
\mathbf{2 0 0 0}\end{array}$ & $\begin{array}{c}\text { Rs 2001 to } \\
\text { Rs 4000 }\end{array}$ & $\begin{array}{c}\text { Rs 4001 to } \\
\text { Rs 6000 }\end{array}$ & $\begin{array}{c}\text { Above Rs } \\
\mathbf{6 0 0 0}\end{array}$ & Total \\
\hline \multicolumn{1}{|c|}{$\begin{array}{c}\text { Month income } \\
\text { Below Rs 3000 }\end{array}$} & 4 & 11 & - & - & 15 \\
\hline Rs 3001 to Rs 6000 & 4 & 15 & 13 & - & 32 \\
\hline Rs 60010 to Rs 9000 & - & - & 5 & 2 & 7 \\
\hline Above Rs 9000 Total & - & - & - & 4 & 4 \\
\hline$\quad 8$ & 26 & 18 & 6 & 58 \\
\hline
\end{tabular}

Source: Compiled from Primary Data.

Monthly income wise savings details

\begin{tabular}{|c|c|c|c|c|}
\hline $\begin{array}{l}\text { Monthly } \\
\text { Savings } \\
\text { Month income }\end{array}$ & $\begin{array}{c}\text { Below Rs } \\
1000\end{array}$ & $\begin{array}{c}\text { Rs } 1001 \text { to } R s \\
1500\end{array}$ & $\begin{array}{c}\text { Rs } 1501 \text { to } R s \\
3000\end{array}$ & Total \\
\hline Below Rs 3000 & 15 & - & - & 15 \\
\hline Rs 3001 to Rs 6000 & 21 & 9 & 2 & 32 \\
\hline Rs 60010 to Rs 9000 & - & - & 7 & 7 \\
\hline Above Rs 9000 & - & - & 4 & 4 \\
\hline Total & 36 & 9 & 13 & 58 \\
\hline
\end{tabular}

Source: Compiled from Primary Data.

\section{Major Findings}

- The monthly income of the sample respondents, the category of Rs. 3001 to Rs. 6000 is the maximum 55.1 per cent and the above Rs. 9000 are minimum 6.9 per cent. It depends upon the occupation of the sample respondents.

- The monthly expenditure on food items of the sample respondents in this present study, the expenditure on food item $\quad$ Rs. 1001 to Rs. 2000 is high 69.0 per cent and the above Rs. 2000 expenditure is the minimum 10.3 percent. It depends upon the monthly income and number of family members of the sample respondents.

- The expenditure on dress materials of sample respondents in this present study. Dress materials expenditure below Rs. 1000 is the maximum 79.3 per cent and the 
above Rs. 2000 is the minimum 8.6 per cent. It depends upon income and lifestyle activities of the sample respondents.

- Expenditure on children's education of the sample respondents, expenditure Rs. 1001 to Rs. 2000 is the maximum 58.6 percent and above Rs. 2000 is the minimum 15.5 per cent. It is clearly shows that the respondents are higher priority to spend the educational purposes.

- The expenditure on fuels of the respondents in this study, expenditure Rs. 1001 to Rs.2000 is the maximum 48.3 per cent and the above Rs. 2000 is the minimum 8.6 per cent. It depends upon the consumption pattern and income of the sample respondents.

- The expenditure on electricity of the sample respondents in this present study, electricity expenditure on Rs. 101 to Rs. 200 is the maximum 58.6 per cent and below Rs. 40 to 100 is the minimum 6.9 per cent. It depends upon the usage of the home appliances.

- The monthly expenditure on social functions of this present study, Rs. 1001 to Rs. 2000 is the maximum 51.7 percent and the above Rs. 2000 is the minimum 13. 8 percent. It depends upon the income and maintain the social status of the sample respondents.

- The monthly expenditure details of the respondents in this study, Rs. 2001 to Rs. 4000 is the maximum 44.8 percent and the above Rs. 6000 is the minimum 10.3 per cent. It depends upon the income and consumption activities of the sample respondents.

- The monthly savings details of the selected sample respondents, the private finance is the maximum 32.8 per cent and the insurance premium is the minimum 10.3 per cent. It depends upon income of the respondents and availability of saving sources.

- The monthly amount of saving of the sample respondents below Rs. 1000 is the maximum 62.1 per cent and Rs. 1001 to $\quad$ Rs. 1500 is the minimum 3.4 per cent. It depends upon the income sources and various saving source of the sample respondents.

\begin{tabular}{|l|c|c|c|c|c|}
\hline Variables & Size & Mean & $\begin{array}{c}\text { Std. } \\
\text { Deviation }\end{array}$ & Pearson Correlation & P Value \\
\hline $\begin{array}{l}\text { Monthly Income } \\
\text { Vs }\end{array}$ & 58 & 22540.3226 & 5969.80162 & & $.000 * *$ \\
$\begin{array}{l}\text { Monthly } \\
\begin{array}{l}\text { Expenditure on } \\
\text { Health }\end{array}\end{array}$ & 58 & 5679.800 & 9286.27 & .318 & \\
\hline
\end{tabular}

There is a significant relationship between the monthly income and monthly expenditure on health in the sample households. Since the $\mathrm{P}$ value is 0.000 , the hypothesis is validated at 1 percent level of significant. Households' monthly income increases the monthly expenditure on health also increase due to increasing disposable income of the 
sample households. It is mainly based on the monthly expenditure of the respondents, age of the family members, and availability of medical facility from Government hospitals and nature of the diseases. Therefore the income increases the monthly expenditure on health also increases.

\section{References}

Benjamin Marx, Thomas Stoker, and Tavneet Suri, 2013. "The Economics of Slums in the Developing World”, Journal of Economic Perspectives, Volume 27, Number 4,

Biplab Das, Utpal Khara, Pradip Giri and Aditya Bandyopadhyay, 2012. "The Challenge of Slum Development in India - A Case Study of Melatala-Dasnagar Slum Area of Howrah Municipal Corporation, International Journal of Advanced System and Social Engineering Research, Vol. 2, Issue 1, 2012.

Dr. S. Kumar Swami, 2017. "An Empirical Study of Growth of Slum Population in India”, International Journal of Political Science, Vol. 3, Issue 1.

John Kaviarasu S and Dr. G. Gladston Xavier, 2015. "The Status of Living Place and the Health Condition of Women in the Slum of Chennai City-Tamil Nadu”, International Journal for Scientific Research and Development, Vol. 3, Issue 08.

Tara Saharan, Karin Pfeffer, and Isa Baud, 2018. "Shifting approaches to slums in Chennai: Political Coalitions, Policy Discourses and Practices" Singapore Journal of Tropical Geography 39, 2018, Pp. $454-471$.

In - text citations

(Benjamin Marx, Thomas Stoker, and Tavneet Suri, 2013, 187-210)

(Biplab Das, Utpal Khara, Pradip Giri and Aditya Bandyopadhyay, 2012, 22 - 27)

(Dr. S. Kumar Swami, 2017, 10-13)

(John Kaviarasu S and Dr. G. Gladston Xavier, 2015, 41-65)

(Tara Saharan, Karin Pfeffer, and Isa Baud, 2018, 454-471) 